\title{
Correction to: Spatial distribution and determinants of iron supplementation among pregnant women in Ethiopia: a spatial and multilevel analysis
}

Chilot Desta Agegnehu*, Getayeneh Antehunegn Tesema², Achamyeleh Birhanu Teshale², Adugnaw Zeleke Alem², Yigizie Yeshaw ${ }^{2,3}$, Sewnet Adem Kebede ${ }^{2}$ and Alemneh Mekuriaw Liyew ${ }^{2}$

Correction to: Arch Public Health 79, 143 (2021) https://doi.org/10.1186/s13690-021-00669-2

Following publication of the original article [1], the author noticed that the first author's family name was incorrectly spelled as "Agegenehu".

The correct spelling of the family name "Agegnehu" has been provided in this Correction.

The original article [1] has been updated.

\begin{abstract}
Author details
${ }^{1}$ School of Nursing, College of Medicine and Health Sciences and Comprehensive Specialized Hospital, University of Gondar, Gondar, Ethiopia. ${ }^{2}$ Department of Epidemiology and Biostatistics, Institute of Public Health, College of Medicine and Health Sciences, University of Gondar, Gondar, Ethiopia. ${ }^{3}$ Department of Physiology, School of Medicine, College of Medicine and Health Sciences, University of Gondar, Gondar, Ethiopia.
\end{abstract}

Published online: 24 August 2021

\section{Reference}

1. Agegnehu CD, Tesema GA, Teshale AB, Alem AZ, Yeshaw Y, Kebede SA, et al. Spatial distribution and determinants of iron supplementation among pregnant women in Ethiopia: a spatial and multilevel analysis. Arch Public Health. 2021;79(1):143. https://doi.org/10.1186/s13690-021-00669-2.

The original article can be found online at https://doi.org/10.1186/s13690021-00669-2

* Correspondence: Chilotdesta@gmail.com

${ }^{1}$ School of Nursing, College of Medicine and Health Sciences and Comprehensive Specialized Hospital, University of Gondar, Gondar, Ethiopia

Full list of author information is available at the end of the article

C C The Author(s). 2021 Open Access This article is licensed under a Creative Commons Attribution 4.0 International License, which permits use, sharing, adaptation, distribution and reproduction in any medium or format, as long as you give appropriate credit to the original author(s) and the source, provide a link to the Creative Commons licence, and indicate if changes were made. The images or other third party material in this article are included in the article's Creative Commons licence, unless indicated otherwise in a credit line to the material. If material is not included in the article's Creative Commons licence and your intended use is not permitted by statutory regulation or exceeds the permitted use, you will need to obtain permission directly from the copyright holder. To view a copy of this licence, visit http://creativecommons.org/licenses/by/4.0/ The Creative Commons Public Domain Dedication waiver (http://creativecommons.org/publicdomain/zero/1.0/) applies to the data made available in this article, unless otherwise stated in a credit line to the data. 